\title{
AGENDA OF RURAL EMPLOYMENT THROUGH MGNREGA: A CASE OF HARYANA (INDIA)
}

\author{
Tarminder Kaur ${ }^{1}$ 迥 \\ ${ }^{1}$ Assistant Professor, Goswami Ganesh Dutta Sanatan Dharma College, Chandigarh \& Research scholar, Panjab University \\ Chandigarh, India
}

\section{ABSTRACT}

The paper is intended to comprehensively analyze the concern of Government for rural development and its various efforts to contain rural problems. Most of all the efforts since independence, MGNREGA is emerged as a milestone and unique initiative to tackle rural poverty through 100 days rural employment. An effort is done to assess the performance of MGNREGA through financial investments in last five years. The actual results have been seen in the form of observing the amount siphoned for labour budget out of total budgetary outlay. Further, to review the social implications, the disadvantaged sections of SCs (Scheduled Caste) and women are specifically considered as beneficiaries.

Received 1 July 2021

Revised 15 July 2021

Published 31 July 2021

Corresponding Author

Tarminder Kaur, tarminder.kr@g mail.com

DOI $10.29121 /$

granthaalayah.v9.i7.2021.4107

Funding: This research received no specific grant from any funding agency in the public, commercial, or not-for-profit sectors.

Copyright: (C) 2021 The Author(s). This is an open access article distributed under the terms of the Creative Commons Attribution License, which permits unrestricted use, distribution, and reproduction in any medium, provided the original author and source are credited.

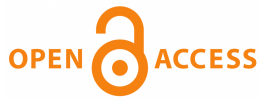

Keywords: Rural development, Social welfare, Rural employment, MGNREGA, Haryana, MGNREGA labour budget, SCs (Scheduled Caste) \& Women

\section{INTRODUCTION}

The word 'Socialist' enshrined in the preamble of Indian constitution expresses the social - welfare nature of State. It lays down various provisions in Indian Constitution in this direction, which are inevitable for the multidimensional development of Indian society. A great Indian nation with its roots in rural India has always been concerned to strengthen its foundation through various social welfare measures for rural India. Directive Principles of State Policy mentioned in Part IV of Indian constitution is guiding principles for the state to take constructive steps for the social welfare of Indian society. Rural development has been the major goal of Government since independence and thus it has taken various initiatives $n$ the form of social welfare schemes, institutional arrangements and legislations.

It cannot be denied that rural development lies in rural people's development. Rural development has been the major thrust area of Government of India in the direction of social welfare of the country. In order to develop the rural people, Government of India has been continuously taking the constructive steps with its main 
focus on rural employment. It was in 1952 when Government started Community Development Programme as a beginning of an era for self awareness among rural communities of India. It would have been a silent revolution if interpreted and adopted by its rural stakeholders which was lacking due to factors like backwardness, illiteracy and lack of interest. Further to overcome, an additional effort was done in the form of democratic decentralization. Panchayati Raj was created in the year 1959 on the recommendation of Balwant Rai Mehta Committee. It was a political rejuvenation of rural India. Afterwards, a flood of various sectoral, sectional and area specific programmes were started by Government of India such as High Yield Variety Programme (1962), Drought Prone Area Programme (1975), Command Area Development Programme (1975), Desert Development Programme (1977-78), Training of Rural Youth for self-Employment (1979), Integrated Rural Development Programme (1979), Development of women and Child in Rural Areas (1982-83), Indira Awas Yojna (1985), Jawahar Rojgar Yojna (1989) and Jawahar Gram Samridhi Yojna (1999) etc. All these social welfare efforts were done in order to bring rural development, betterment of rural people's lives and thus rural prosperity.

\section{MGNREGA}

Despite all these constructive measures, rural India has always been plagued with poverty and unemployment. With the passage of time, there emerged a need for a holistic approach for an all encompassing development of rural India. The socioeconomic condition of rural people is directly linked to the rural development and thus there is a clear cut nexus between rural poverty and unemployment. The focus on infrastructure development and sectoral approaches only are not enough to cater the problem of unemployment and poverty in rural India. Responding to these rural challenges, Government of India moved ahead with one more social welfare measure in 2005, known as MGNREGA. Ministry of Rural Development, Government of India introduced a rural employment programme to improve the economic life of rural people.

The act came into force on February 2, 2006 and was implemented in a phased manner. In phase I, it was introduced in 200 of the most backward districts of the country. It was implemented in an additional 130 districts in phase II 2007-2008. The Act was notified in the remaining rural districts of the country from April 1, 2008 in phase III. All rural districts were covered under Mahatma Gandhi MGNREGA. The Mahatma Gandhi National Rural Employment Guarantee Act, 2005 (MGNREGA) was notified on September 7, 2005. The mandate of the Act is to provide a 100 days of guaranteed wage employment in a financial year to every rural household whose adult members volunteer to do unskilled manual work. (Vyas (2018) ).

The Act stipulates that wages will be equal for men and women. Schedule II paragraph 6 of MGNREGA Act, 2005 provides for participation of women in employment generated under the Act. It specifically provides that at least $33 \%$ of the women who 
have requested for employment should be provided employment Tiwari (2015) .

\section{THEORETICAL REVIEW}

A. Sharma (1994) in "Rural Employment Programme in India" comprehensively analyzed the efforts of government for rural development and to reduce poverty. The detailed analyses of "National Rural Employment Programme (1980) was conducted in this direction. Srivastava and Srivastva (2010) Srivastava and Srivastava (2010) in their work "Women, work and Employment outcome in Rural India" focused on the importance of work in women's life. R. K. Sharma (1997/2011) in "Rural Sociology" highlighted the role of TRYSEM, IRDP, and DPAP etc. to reduce rural poverty. Puthenkalam and George (2012) stressed upon the economic life of rural People in his work "Human Development strategy of MGNREGA". Borah and Bordoloi (2014) conducted a case study in Sonitpur district of Assam to assess the impact of MGNREGA on women's life. Tiwari (2015) highlighted the role of MGNREGA in gender equality. Ravindar (2016) conducted a case study in warangal district to find out the role of MGNREGA in women's life. Vyas (2018) conducted a detailed analysis on functioning of MGNREGA and its outcomes in the form work profile, wage structure, MGNREGA's gender sensitivity and its impact on rural livelihood.

\section{RESEARCH METHODOLOGY}

The study is in the form of descriptive analysis based on statistical data available with Government of Haryana. Secondary sources have been used to make a detailed analysis of Government's continuous concern for rural development through MGNREGA.

\subsection{OBJECTIVES OF THE STUDY}

1. To draw a comparison of budgetary outlays for MGNREGA in last five years in the state of Haryana

2. To find out the outcomes of MGNREGA in terms of Labour budget

3. To provide an overview about the social implications of MGNREGA through SCs and women participation

\section{DISCUSSION}

The Act emerged as a milestone achievement in the world of rural social-welfare and it is thriving on its road to become an antidote to multifarious rural problems. It is a socio-economic, gender sensitive and rural developmental programme aims at bringing gender parity, creating employment at doorstep, leading to financial inclusion through rural local developmental projects. MGNREGA, a national level endeavor of Government of India thrived at each and every corner of India. It is legislation, continuously contributing to tackle the problem of unemployment throughout rural India. 
In North India, rural people are equally taking full advantage of employment under MGNREGA. From economic perspective, center Government invest a candid amount in MGNREGA through Ministry of Rural Development. Taking into consideration the consequent economic investment in MGNREGA for last three years, it is observed that figures have dwindled in the budget 2020-21, as compared to 2019-20. For the noble cause of rural development, an amount of 71,001.81 crore was sanctioned for MGNREGA in the budget 2019-20 whereas it was 61,500 crore during the budget of 2020-21. Accordingly, it was directly shrinked and went down by more than $13 \%$ which is not a desirable indication when MGNREGA is becoming a popular mode of employment in rural India day by day. Further, budgetary allocation positively fluctuated during the budget 2021-22, when an amount of 73000 crore was allocated to MGNREGA which is a sharp hike than last year's budgetary allocation. Though, it manifests Government's sincere concern for rural employment but considering the wide ranging impact of covid-19 pandemic, the budgetary allocation seems to be less than sufficient. The pandemic created a great havoc in the form of unemployment, when a vast labour force became unemployed due to economic shut down. There was not any other option than going back to their rural homes and it has created a huge rush of unemployed population in rural India. In this scenario, there was a great demand for employment under MGNREGA. Thus, it seems that the allocation of 73000 crore is insufficient to tackle the huge labour force in rural India. PAEG (People's Action for employment guarantee), an active civil society group said that the budgetary amount of 2021-22 is much lower than the revised estimate of Rs. 1.11 lakh crore.

\subsection{ASSESSMENT OF MGNREGA IN HARYANA (2016-21)}

Haryana is a state carved out of Punjab on November 1, 1966. Presently it consists of 22 districts, 140 blocks and 6214 villages. The state has been on the forefront in executing MGNREGA with higher wage rates with exemplary outcomes which has far reaching impact on the rural population. Taking into consideration the last five years progress of MGNREGA in Haryana, it cannot be denied that continues efforts are being done to achieve the desired objectives of rural employment and rural development through this legislation.

\section{Table 1 Financial Progress of MGNREGA in Haryana}

\begin{tabular}{llllll}
\hline $\begin{array}{l}\text { Financial } \\
\text { Progress }\end{array}$ & FY 2020-21 & FY 2019-20 & FY 2018-19 & FY 2017-18 & FY 2016-17 \\
$\begin{array}{l}\text { Total center } \\
\text { Release }\end{array}$ & 74451.73 & 34526.69 & 35625.15 & 30140.64 & 28771.33 \\
$\begin{array}{l}\text { Total avail- } \\
\text { ability }\end{array}$ & 78457.05 & 37582.34 & 40281.99 & 33245.24 & 32391.57 \\
$\begin{array}{l}\text { Percentage } \\
\text { utilization }\end{array}$ & 93.17 & 103.23 & 91.33 & 96.18 & 100.47 \\
\hline
\end{tabular}

Continued on next page 


\begin{tabular}{lccccc}
\hline \multicolumn{5}{c}{ Table 1 continued } \\
\hline $\begin{array}{l}\text { Total Expen- } \\
\text { diture }\end{array}$ (In & $73,095.38$ & $38,794.7$ & $36,788.4$ & $31,976.24$ & $32,542.83$ \\
$\begin{array}{l}\text { Lakhs) } \\
\text { Wages (In }\end{array}$ & $53,882.65$ & $26,592.25$ & $22,464.22$ & $24,868.42$ & $23,087.47$ \\
Lakhs)
\end{tabular}

Source: https://mnregaweb2.nic.in/netnrega/homestciti.aspx?state_code=12\&state_name=HARYA NA

The overall financial investments are ever increasing during last five years in the state of Haryana. Simultaneously the total availability of the funds has been more than the total center release for every year since 2016 to 2021. It shows a sincere concern of the state for MGNREGA which is a crucial factor in successful implementation of the Act in any state. It cannot be denied that finance is the only lifeline for MGNREGA's success and thereby data shows that the state Government has always kept plenty of funds for MGNREGA functioning. Except financial year 2016-17 and financial year 2019-20, the percentage funds utilization did not exceed. Table 1.3 shows that during last five years, a major sum of the total available funds has been utilized in the payment of MGNREGA which is an expected and actual outcome of the legislation. The share of MGNREGA wages in total MGNREGA budget has been consequently increasing except financial year 2018-19. It provides real evidence that this major rural employment programme is positively impacting the lives of rural unemployed people by providing 100 days employment in a year.

\begin{tabular}{|c|c|c|c|c|c|}
\hline Progress & $\begin{array}{l}\text { FY } \\
2020- \\
21\end{array}$ & $\begin{array}{l}\text { FY } \\
2019- \\
20\end{array}$ & $\begin{array}{l}\text { FY } \\
2018- \\
19\end{array}$ & $\begin{array}{l}\text { FY } \\
2017- \\
18\end{array}$ & $\begin{array}{l}\text { FY } \\
2016- \\
17\end{array}$ \\
\hline Approved Labour Budget (In Lakhs) & 170 & 100 & 100 & 100 & 98 \\
\hline Person days generated so far (In Lakhs) & 174.2 & 91.19 & 77.9 & 90.37 & 84.92 \\
\hline Percentage of total labour Budget & 102.47 & 91.19 & 77.9 & 90.37 & 86.65 \\
\hline SC person days $\%$ as of total person days & 36.12 & 42.14 & 45.58 & 47.66 & 50.01 \\
\hline Women person days $\%$ as of total person days & 48.74 & 50.59 & 50.05 & 48.64 & 45.62 \\
\hline Total Households worked (In Lakhs) & 4.51 & 2.58 & 2.31 & 2.73 & 2.81 \\
\hline $\begin{array}{l}\text { Total number of Households completed } 100 \\
\text { days of wage employment (In Lakhs) }\end{array}$ & 12,920 & 4,831 & 3,789 & 3,924 & 2,459 \\
\hline
\end{tabular}

Source: https://mnregaweb2.nic.in/netnrega/homestciti.aspx?state_code=12\&state_name=HARYA NA

*SC: Scheduled Caste *FY: Financial Year

It is observed from the investments done in MGNREGA in last five years since 2016 that labour budget has increased over the years. Though it has been stable during the financial years 2017-18 to 2019-20 but drastically increased in financial year 202021. At the same time, it is also noticeable that despite the drastic increase during 2020-21, the labour budget exceeded the limit by $102.47 \%$ whereas the labour bud- 
get has been in surplus during last financial years since 2016. It exhibits the increase in rural labour force during Covid-19 pandemic when a huge number of manual wage labour returned to their native homes from urban centers. MGNREGA emerged as a legislation with wider social impact on rural Indian society as it engulfed huge rural unemployed force including SC (Scheduled Caste) population and women also. Data shows that the participation of SC population in MGNREGA has decreased consecutively since 2016 to 2021 from $50.01 \%$ to $36.12 \%$. MGNREGA has also maintained the gender sensitivity by keeping 33\% employment for women. In the state of Haryana, it has wide ranging implication beyond $33 \%$ and around $50 \%$ employment is availed by women workforce. The increasing trends are shown during the financial year 201617 to 2019-20 but reduced to 48.74\% I the financial year 2020-21. The total number of households employed under MGNREGA has increased from 2.81 Lakhs in the financial year 2016-17 to 4.51 Lakhs in 2020-21. It manifests an impressive and desirable performance of MGNREGA in Haryana which is moving forward to achieve the actual intended goals of this noble legislation. MGNREGA ensures 100 days employment to rural population beyond any social cleavages and gender inequalities. Thus, it has been successful to cater the employment need at doorsteps of rural people.

Unemployment is a major problem in India that breeds various other types of other social problems such as illiteracy, poverty and unemployment etc. Poverty is the root cause of various socio- economic disabilities that hinders all round development of an individual. In this scenario, at least 100 days of employment is also helpful to curb the menace of poverty to a large extent. Thus, generating employment at door step level through MGNREGA means tackling and overcoming various social problems at the same time. The success of MGNREGA is highly dependent on political and administrative will for its effective execution. In this direction the possibility of some limitations and loopholes at administrative level cannot be denied. The malpractices like corruption, embezzlements and delay in payments can hinder the smooth and efficient implementation of MGNREGA. Thus, there is a need to bring transparency and effectiveness in MGNREGA execution at each administrative level so that the benefits can be reached to intended beneficiaries in time.

A change in approach is required to improve livelihood standards - a shift from subsistence living to a developed one - a move from unskilled work to semi skilled ones. This requires adding those types of work that can uplift the people from poverty and distress in rural areas from poverty; it can move from the preventive approach to a progressive one (Tiwari (2015) ).

Jean Dreze, an economist-cum-activist who put his sincere efforts in the formation of this worldly renowned rural employment programme admitted that there is a need of reforms in MGNREGA to overcome various malpractices. Though he admitted that various efforts have been done to control these malpractices such as fund leakages through bank payment of wages, social audit and computerization of records but still he insist that there is a need to bring more transparency, simplification of complicated administrative procedures . Jean Dreze, popularly known as people's 
economist further said that in the name of Aadhar based payments and Direct benefit transfers, there are more cases of rejected, diverted and locked payments along with the old problem of delayed payments.

\section{CONCLUSION}

It is true that MGNREGA is emerged as an antidote to rural poverty to a large extent. The financial figures of last five years since 2016-17 to 2020-21 in the State of Haryana show an ever growing concern of both Center and State Governments for Rural development through rural employment. Data shows that a huge amount of total MGNREGA budget is spent on MGNREGA wages which is equally availed by disadvantaged sections of society such as SCs and women. These sections can be considered as deserving and intended beneficiaries of this legislation. Providing employment to these sections of society directly leads to empowerment of rural masses. The legislation is multidimensional in nature catering the twin objectives of building rural infrastructure and eradicating rural poverty, thus strengthening the foundation of Indian state. Various administrative and financial lacunas should be seriously handled to achieve the desired targets under MGNREGA. At the same time, there is a need to fuel more spirit in MGNREGA's execution through political will, administrative efficiency, whole hearted support of civil society and awareness among rural masses.

\section{REFERENCES}

Borah, K., \& Bordoloi, R. (2014). MGNREGA and its Impact on Daily Waged Women Workers: A Case study of Sonitpur District of Assam. IOSR Journal of Economics and Finance (IOSR$J E F), 4(4), 40-44$. Retrieved from http://www.iosrjournals.org/iosr-jef/papers/vol4 -issue4/F0444044.pdf

Puthenkalam, J. J., \& George, G. (2012). Human Development Strategy of MGNREGA. Jaipur. Rawat Publications.

Ravindar, M. (2016). EMPOWERMENT OF WOMEN THROUGH MGNREGS: A STUDY IN WARANGAL DISTRICT OF TELANGANA STATE. International Journal of Multidisciplinary Research and Modern Education (IJMRME), 2(1), 309-321. Retrieved from http://rdmodernresearch.org/wp-content/uploads/2016/04/176.pdf

Sharma, A. (1994). Rural Employment Programme in India. New Delhi. Mohit Publications. New Delhi. Mohit Publications.

Sharma, R. K. (1997/2011). Rural Sociology. New Delhi. Atlantic Publishers.

Srivastava, N., \& Srivastva, R. (2010). Women, Work and Employment outcome in Rural India. Retrieved from http://www.jstor.org.iproxy.inflibnet.ac.in:2048/stable/pdf/ 40736730.pdf?refreqid=search\%3A70eaaac695401fa2c04b7bf5e17c8f05

Tiwari, N. (2015). MGNREGA and Gender Equity. New Delhi. Kanishka Publishers and distributors. p. 24, 115.

(2021). Re.trievedaccessed on 08/03/2021 at 9:36 pm, from http://ruraldiksha.nic.in/ daily/sancrelease/repschemebt1415.asp?dept_code=rd\&scheme_cod=26\&financial _year $=2020-2021$

(2021). Re.trievedaccessed on $08 / 03 / 2021$ at 10:01 pm, from https://economictimes 
.indiatimes.com/news/economy/policy/budget-2020-mgnrega-funds-down-by-13 -marginal-dip-in-other-rural-development-schemes/articleshow/73847723.cms ?from $=\mathrm{mdr}$

(2021). Re.trievedaccessed on 16/03/2021 at 08:35 pm, from https://economictimes indiatimes.com/opinion/interviews/nrega-is-in-need-of-reform-jean-dreze -economist-cum-activist/articleshow/45117070.cms?from $=\mathrm{mdr}$

(2021). Re.trievedaccessed on 22/03/2021 at 11:52 am, from https://mnregaweb2.nic.in/ netnrega/homestciti.aspx?state_code=12\&state_name=HARYANA

(2021). Re.trievedaccessed on 08/03/2021 at 10:15 pm, from https://www.downtoearth .org.in/news/governance/is-union-budget-2021-22-mgnrega-allocation-enough-to -alleviate-rural-distress-75292

(2021). Re.trievedaccessed on 16/03/2021 at 08:37 pm, from https://www.financialexpress .com/economy/jean-dreze-exclusive-mgnrega-workers-have-become-guinea-pigs -for-aadhaar-payments-system/1246759/

(2021). Re.trievedaccessed on 16/03/2021 at 08:58 pm, from http://www.haryanarural.gov in/en/budget

Vyas, A. (2018). Sociological analysis of MGNREGA. Jaipur.Book Enclave. p. 23-24. 